\section{MAMMARY CANCER IN MICE}

T the introduction to this collection of essays*, Dr. M. B. Shimkin sketches the historical development of our knowledge of mammary cancer in mice. Dr. E. F. Bashford and his colleagues of the Imperial Cancer Research Fund were instrumental in establishing the validity of using animal tumours in experimental cancer research. Then Leo Loeb and others showed the important part played by hormones in mammary cancer. By developing and using inbred. strains of mice, American workers were able to investigate the inheritance of mammary cancer and reveal the existence of extrachromosomal influence. The cytology, morphology and histogenesis of the mammary gland and mammary tumours are discussed in four illustrated contributions. In general, only minor advances have been made in the morphology of mammary tumours since the classical work carried out early in the present century. Dr. W. E. Heston reviews our knowledge of the genetics of mammary cancer in mice and describes the origins and characters of the inbred strains of mice used in cancer research. This work can be considered to have commenced in 1909, when Dr. C. C. Little started breeding the $c b a$ strain, although some evidence that the tendency to mammary cancer was inherited was available before that time.

The development of knowledge of the milk influence on the genesis of mammary tumours is reviewed by Dr. H. B. Andervont. Early experiments showed that in reciprocal matings between strains with high and low mammary tumour-rates, the mice born to high-cancer strain mothers develop cancer, while those born to low-cancer strain mothers remain relatively free of tumours. The extra-chromosomal factor influencing the incidence was shown by Dr. J. J. Bittner, in a series of foster-nursing experiments, to be present in the milk of high-cancer strain mice. The relative incidence of tumours and the latent period for the appearance of tumours in certain strains of mice vary with the dose of the milk factor, and the response can be used for the biological assay of the factor. The milk factor appears to be a nucleoprotein and is widely distributed in the tissues of high-cancer strain mice. As the effect can be transmitted through mice without inducing tumours, the factor acts like a latent virus infection. It differs from known viruses in its relatively long latent period. Early experiments with heterozygous mice showed that mammary cancer was generally more common in breeding than in virgin mice, and that the incidence was reduced by ovariectomy. The importance of ostrogenic hormones in the incidence of mammary cancer could only be clearly shown by treating male mice of high-cancer strains which had both chromosomal and extra-chromosomal factors for cancer.

The relatively uniform behaviour of mice from inbred strains also makes it possible to study the effects of diet on the incidence and growth of mammary tumours. Dr. H. P. Morris describes many different experiments in which restriction of food intake or utilization has reduced the incidence of cancer or retarded the growth of existing tumours. In their chemical constituents and biochemical processes, mammary tumours resemble other tumours more closely than normal breast tissue. Dr. J. P. Green-

* Mammary Tumours in Mice. A Symposium by Members of the Staff of the National Cancer Institute, National Institute of Health, United States Public Health Service. Publication No. 22. Pp. v+223. (Washington, D.C.: American Association for the Advancement of Science, 1945.) stein points out that the end results of neoplastic growth are tissues which are chemically similar. The range of activity of several enzymes is much smaller among different tumours than among normal tissues. Mammary tumours in mice have been used extensively for experiments on chemotherapy of cancer, and Dr. Helen H. Dyer, in summarizing and tabulating the work in this field, concludes that no effective remedy has yet been found. Breast tumours in mice form the most valuable material available for such experiments. The probability that the cure for one type of cancer may not work on all types of tumour, however, makes it advisable that more than one type of tumour should be used in therapeutic experiments.

In the concluding essay, Dr. M. B. Shimkin considers the possible implications of the work on mice to human cancer. Whether mammary cancer in women is inherited is not yet known with certainty, so that we cannot say if a milk factor operates in humans or not. Even so, Dr. J. J. Bittner has suggested that it might be desirable to interrupt completely the nursing of daughters in whose family history carcinoma of the breast has occurred.

Mammary tumours in mice have been extensively studied, and the facts which have been obtained are well presented in this symposium. To what extent other tumours, or mammary tumours in other species, resemble these mouse tumours, particularly from the point of view of heredity, remain as interesting problems for the future. E. Boyland.

\section{STUDIES ON COMPREGNATED WOOD}

TXPERIMENTS carried out at the Forest Research Institute, Dehra Dun, indicate that compregnated wood which compares favourably with foreign samples (tests on a foreign specimen of compregnated birch are given) can be produced from Indian timbers. In Indian Forest Leaflet No. 77-1945 (Utilization) entitled "Preliminary Studies on Improved Wood, Part III. Compregnated Wood" (published by Forest Research Institute, Dehra Dun, 1945), it is stated that wood of highly improved properties can be obtained by a suitable combination of impregnation, lamination and compression. In the case of compressed wood and lignostone, whole wood scantlings are used and, by application of great compression, the properties of the material are made uniform in the main direction. In the case of compregnated wood, the timber is sub-divided into veneers, and impregnated with resins, or thin films of glue are placed between the veneers; finally the pack is compressed at a high pressure at a suitable temperature. Alcoholic solutions of resin or film glues, such as Tego film, etc., are used. It is said that by suitable choice of the species of wood, thickness of the veneers, pressure and temperature employed, and the direction of laying the veneers, the properties of the resulting material can be varied to meet particular requirements. The uses of this material, it is held, are very varied-aeroplane propeller blades are given as an example. The main defects of natural wood in this connexion are low hardness; low cleavage strength; low shear strength and great hygroscopicity. Compregnated wood, on the other hand, has high tensile strength; high shear strength to cope with the high centrifugal stresses at the boss, 
which at the same time are reduced to a minimum due to the low density of the material in contrast to metal ; high damping capacity ; favourable strength density ratio; lightness (weight of such blades are a third of metal ones); increases in efficiency (about 6 per cent) by the use of such blades ; ease of repair ; and finally, it is claimed, freedom from tiring, which is so frequently the cause of fatal air accidents in aeroplanes fitted with metal propellers. Other uses are gear wheels, bearings (ships' tail shafts, rolling mills, textile mills, etc.), fish plates, press forms, gun stocks, electrical machinery and so forth.

For the preparation of eompregnated wood in the investigations, rotary cut, sawn or sliced veneers of different Indian timbers were used, some twentythree species being experimented with. The adhesives employed were tar acid formaldehyde resins prepared in the laboratory, prolamin-formaldehyde dispersions, casein-formaldehyde dispersions or a suitable combination of these materials. The Leaflet, which is illustrated with photographs and tabular diagrammatic statements, discusses the methods and procedure employed in the investigation.

\section{FORTHCOMING EVENTS}

Saturday, December 29

ROYAL INSTITUTION (at 21 Albemarle Street, London, W.1), at 2.30 p.m.-Sir Robert Watson-Watt, F.R.S.: "Wireless" (Christmas Lectures adapted to a Juvenile Auditory, 2).

Tuesday, January I

ROYAL INSTINTTION (at 21 Albemarle Street, London, W.1) at RO p.m.-Sir Robert Watson-Watt, F.R.S.: "Wireless"' (Christmas Lectures adapted to a Juvenile Auditory, 3 ).

TELEVISION SOCIETY (at the Institutjon of Electrical Engineers, Savoy Place, Victoria Embankment, London, W.C.2), at 6 p.m.Mr. F. A. Inskip : "A Test Signal Generator for Television Receivers"; Mr. A. M. Spooner: "Cathode Ray Tube Quality Measuring Apparatus".

Wednesday, January 2

ROYAI SOCIETY OF ARTS (at John Adam Street, Adelphi, London, w.C.2) at 2.30 p.m.-Dr. C. B. Williams: "The Migration of Butterflies" (Dr. Mann Juvenile Lectures, 1).

Thursday, January 3

ROYAL INSTITUTION (at 21 Albemarle Street, London, W.1), at 2.30 p.m. - Sir Robert Watson-Watt, F.R.S.: "Wireless"' (Christmas Lectures adapted to a Juvenile Auditory, 4)

ROYAT COLLEGE OF SURGEONS OF ENGLAND (at Lincoln's Inn Fields, London, W.C.2), at 5 p.m.-Mr. N. L. Capener: "Physiological Rest-the Orthopædic Principle". Association FOR SCIENTIFIC PHoTOGRAPHX (in the Theatre of the
British Council, 3 Hanover Street, London, W.1), at 6.15 p.m.-Dr. A. J. Holland: "GIass and Photography".

\section{Friday, January 4}

BRITISH ECOLOGTCAL SOCIETY (in the Washington Singer Laboratories, Prince of Wales Road, Exeter), at 10 a.m. - Annual General Meeting.

INSTITUTE OF PHYSIOS, ELECTRONICS GROUP (at the Royal Society, Burlington House, Piccadilly, Iondon, W.1), at 5.30 p.m.-Prof. N. Feather, F.R.S.: "Artificial Radioactivity".

\section{Saturday, January 5} ROYAL INSTITUTION (at 21 Albemarle Street, London, W.1), at
2.30 p.m.-Sir Robert Watson-Watt, F.R.S.: "Wireless" (Christmas Lectures adapted to a Juvenile Auditory, 5).

Monday, December 31-Saturday, January 5

TWENTY-NINTH ANNUAL CONFERENCE OF EDUCATIONAL ASSOCIA. moNs (at King's College, Strand, London, W.C.2).

Wednesday, January 2

At 5 p.m. (in the Great Hall).--Lady Simon: "The School, the Teacher and the Home" (Presidential Address).

Thursday, January 3

At 2.30 p.m. (in the Great Hall).-Discussion on "The Teacher" Profession" (to be opened by Mrs. M. D. Stocks and Mr. Nigel 0 . Parry).

\section{APPOINTMENTS VACANT}

APPIICaTions are invited for the following appointments on or before the dates mentioned

ASSISTANT BURSAR-The Bursar, Queen's University, Belfast (January 10)

PRINCIPAL - The Clerk and Treasurer, Dundee Institute of Art and Technology, Bell Street, Dundee (January 12).

Patent AGENT (qualified), preferably holding an Fingineering Degree or equivalent qualification, by a large Engineering Company, electrical and mechanical-The Ministry of Labour and National Service, Appointments Department, Technical and Scientific Register,
Room 572, York House, Kingsway, London, W.C.2, quoting F.5222.XA January 12)

DEPUTY BOROUGH ENGINEER AND SURVEYoR-The Town Clerk, Town Hall, St. Marylebone, London, W.1, endorsed 'Deputy Borough Engineer and Surveyor' (January 12).

LECTURER IN HAUSA-The Director, School of Oriental and African Studies, University of London, London, W.C.1 (January 15).

ARCHAOLOGIST (man or woman)-The Keeper of the Museums, Yorkshire Museum, York (January 31).

Professor of ChEMIstry-The Principal, Heriot-Watt College, Edinburgh (April 22).

PROFESSORSHIP OF INDUSTRIAI CREMISTRY at Istanbul University -The British Council (Appointments Department), 3 Hanover Street, London, W.1.

BAOTERIOLOGIST to work on the intestinal flora, a BrocHEMIST with good bacteriological knowledge for microbiological assay of the vitamins, and an ORGANIC or BIO-CHEMIST for other work involving vitamin assay-The Secretary, National Institute for Research in Dairying, Shinfield, Reading.

CHEMISTs (male), Inter. B.Sc. standard, as Assistant Works Chemists with large firm of cement manufacturers-The Ministry of Labour and NationaI Service, London Appointments Office, 1-6 Tavistock Square, London, W.C.1, quoting Ref. No. C.N.68.

\section{REPORTS and other PUBLICATIONS} (not included in the monthly Books Supplement)

\section{Great Britain and Ireland}

Radar: a Report on Science at War. Released by the Joint Board on Scientific Information Policy for Office of Scientific Research and Development, War Department, Navy Department. Pp. 50. (London: H.M.' Stationery Office; Washington, D.C. : Government Printing Office, 1945.) 18. net.
The Scientifle Civil Service: Reorganization and Recruitment during the Reconstruction Period. (Cmd, 6679.) Pp. 16. (London H.M. Stationery Office, 1945.) 3d. net. The Administrative Class of the Civil Service. (Cmd. 6680.) Pp. 16. (London: H.M. Stationery Office, 1945.) 3d. net. Report by the Geological Sub-Committee of the Nature Reserves Investigation Committee. Memorandum No. 5 : National Geological Reserves in England and Wales. Pp. iv +42 . (London: Society for the Promotion of Nature Reserves, c/o British Museum (Natura A New Deal for Government Scientists? Pp. 12. (London : Institution of Professional Civil Servants, 1945.)

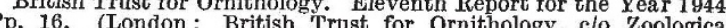
Pp. 16. (London: British Trust for Ornithology, c/o Zoologica West India Roval Commission Report. (Cmd, 6607) Pp xvili $480+16$ plates. (London: H.M. Stationery Office, 1945.) 7s. $6 d$. net.

\section{Other Countries}

Bulletin of the American Museum of Natural History. Vol. 84 : The North and South American Ascidians. By Dr. Willard G. Van Name. Pp. vii $+476+31$ plates. (New York: American Museum of Natural History, 1945.)

Contributions from the United States National Herbarium [98 29, Part 2: Mexican Phanerogams described by M. E. Jones, by Western United States by M. E. Jones, 1908-1935, by S. F. Blake. western United States by M. E. Jones, 1908-1935, by S. F. Blake. Pp. xi $+87-138$. (Washington, D.C.: Government Printing Office, Proceedings of the United States National Museum. Vol. 96, No. 3193: The Ichneumon-Flies of the Genus Cryptanura Brulle, mainly Tropical American. By R. A. Cushman. Pp. 139-176. Vol. 96, No. 3194: Neotropical Lanternflies of the Genus Phrictus in the United States National Museum, with Descriptions of Four New Species. By John S. Caldwell. Pp. 177-184. (Washington, D.C.: Government Printing Office, 1945.)
Biological Abstracts. Report for 1944. By John E. Flynn. Pp. 12. Biological Abstracts. Report for 1944. By John E. Flynn. Pp. 12.
[9hiladelphia: University of Pennsylvania, 1945.) Gold Coast Colony. Forestry in the Northern Territories of the Gold Coast. By R. C. Marshall. Pp. 12. (Accra : Government Print. ing Oflice, 1945.) 1s. December 31, 1944. Pp. 394. (Philadelphia: American Philosophica Society, 1945.)

\section{Catalogues}

High Vacuum for Industry. Pp. 30. (Boston, Mass.: National Research Corporation, 1945 .

Books of All Ages on Varied Subjects. (Catalogue No. 676.) Pp. 70 London: Francis Edwards, Ltd., 1945.)

Libros de medicina, farmacia y veterinaria. Pp. 64. (Madrid Libreria Casas y Buendia, 1945.) 